\title{
London and Frankfurt in Europe's evolving financial centre network.
}

\author{
James R Faulconbridge \\ Department of Geography, \\ Loughborough University, \\ Loughborough, \\ Leicestershire, \\ LE11 3TU, \\ U.K. \\ Email for correspondence: j.r.faulconbridge@lboro.ac.uk
}

\section{Full reference}

Faulconbridge (2004) London and Frankfurt in Europe's evolving financial centre network. Area 36.3, 235-244. 


\title{
London and Frankfurt in Europe's evolving financial centre network.
}

\begin{abstract}
The launch of the Euro and the location of the European Central Bank in Frankfurt was initially seen as a threat to London's pre-eminent position in European financial geographies. This paper explains why this was in fact not the case. The paper is therefore divided into two sections. Firstly it reviews the literatures that help to explain financial geographies. It is argued that we need to move away from investigating attribute properties such as financial turnover and instead examine the role of networks and interdependencies in producing financial geographies. Secondly, it identifies London's dominance and Frankfurt's growth as a complementary centre through quantitative analysis and then explains how European networks and interdependencies produce this based on insights from interviews with investment bankers and insurance institution workers in the two cities.
\end{abstract}

\section{Keywords:}

International financial centre network; Europe; Interviews; Financial geographies; London; Frankfurt. 


\section{Introduction}

Geographers have long been asking what compels financial services to remain embedded within International Financial Centres (IFC's) when technology would seem to facilitate de-concentration and geographical dispersion (O'Brien, 1992). Such questions have been comprehensively answered (Budd 1999; Taylor et al, 2003) but the dynamics of the financial system mean these geographies cannot be assumed to be static. One significant economic transformation has been the launch of Economic Monetary Union (EMU) and the Euro in January 1999 which raised questions about the continuation of established European financial geographies. As an IFC London is accustomed to its dominant role in Europe. This gives it not only financial supremacy built on an agglomeration of producer service firms (Thrift 1987) but also has effects on the city's built environment and strategic planning (Pryke, 1994) and its business culture (Thrift, 1994; Thrift and Leyshon, 1992). However, The Financial Times (FT) was awash with articles leading up to the launch of the Euro questioning the implications of London being outside of EMU and the European Central Bank (ECB) locating in Frankfurt. This was said to possibly mean "a battle between London and Frankfurt" (FT $7^{\text {th }}$ July 1998) and a "bitter war for supremacy" (FT 10 ${ }^{\text {th }}$ July 1998). Similarly, Fairlamb (1999) talked of the 'dueling markets' developing between London and Frankfurt because of EMU's implications. Moreover, although Frankfurt was seen as a small IFC because of its weak historical legacy in a decentralised urban system (Holfrerich, 1999) the city had began to strive for a more international role (Keil and Ronneberger, 1994; Schamp, 1999). Less than 10 years ago then London's future as Europe's pre-eminent IFC seemed far from assured (see Johnston, 1996; Leyshon and Thrift, 1992). However the reality today contradicts those views with London continuing to be the dominant European IFC. As HM Treasury $(2003,162)$ in their analysis of the impacts of the UK's position outside of EMU suggests, as regards attracting new business "[t]he strength of the City in international wholesale financial services activity should mean that it continues to do so, 
whether inside or outside EMU". It therefore seems that we need to consider new ways of conceptualising IFC geographies in order to explain London's continued dominance. The aim of this paper then is to argue that London exists in a network of IFC's rather than just as the apex of the European hierarchy as is often portrayed and that it is this network that has sustained its pre-eminence.

The rest of the paper is therefore divided into four sections. In the following section the paper evaluates the existing literatures on IFC's which view them as independent centres with their location in a hierarchy determined by competitive attribute properties. In section two it introduces the notion of networks in order to provide a new conceptual framework for understanding European IFC's. The idea of network relations and important spaces of flows between IFC's are discussed as a way of improving previous analyses and explaining the continued dominance of London. In section three both quantitative data on financial centres and qualitative interviews with senior personnel of institutions in London and Frankfurt are used to highlight the role of these processes in sustaining London's dominance and aiding Frankfurt's development as a complementary centre. The final section provides conclusions suggesting how we may interpret these findings and their significance for the way we study IFC networks in contemporary globalisation. It is proposed that instead of accepting a simple hierarchical view of the geography of IFC's we need a relational, networked analysis to understand London's continued dominance which is based on network interdependencies providing global-local ties, connectivity and relationships with other IFC's.

\section{Hierarchical explanations of IFC geographies}

Geographers have long had an interest in IFC's. The work of Howard Reed (1981) exemplifies this in which he ranked IFC's based on their importance in the global 
financial system and suggested that to be an IFC required both the ability to handle and the presence of a high volume of financial transactions ${ }^{i}$. He produced a hierarchy of 80 IFC's in 40 countries with 5 functional divisions. Table 1 shows the top ten IFC's identified by Reed. This work proved seminal for the study of IFC's but failed to answer one of Reed's own questions, that being that in studies "missing are the factors required in the building of IFC pre-eminence" (Reed, 1981, viii.) In producing a hierarchy Reed simply identified the different attributes of each centre rather than the processes which produced them.

\{ Insert table 1 here $\}$

Reed's question has partially been answered by reference to the historical dimensions of IFC's growth. For London the role of empire and the global trading links produced are seen as critical with the Lloyds insurance market and its global reach being one of the most well known outcomes (Michie, 1991). Explanations have been further advanced by Thrift (1987) who noted the importance of other producer service firms in supporting IFC growth, something which is now central to agglomeration theories (see Sassen, 2000). Scholars have also highlighted three other attributes that explain hierarchical geographies of IFC's.

Firstly, the role of national regulatory factors as an important attribute determining an IFC's success has been noted (Pryke, 1991; Budd, 1995). An accommodating regulatory environment it was argued gives certain IFC's "comparative advantage over some territories" (Budd, 1995, 352) with for example the de-regulation of pension funds benefiting cities like London as new markets emerged around pension fund management and investment (Clark, 2001). In recent times however many have become increasingly aware of the diminishing role such a process may have upon IFC geographies (e.g. Martin, 1999) as supra-national agreements on regulation and 
financial standards mean the advantages of any one city have diminished (Roberts 2002; Tickell 1999). Budd $(1999,133)$ revised his argument and suggested this created a 'crisis of embeddedness' as '[t]he fundamental shift in the regulatory space of the production economy is being followed by a shift in the financial economy" and no IFC's role could be assured by national regulatory advantage alone.

Secondly, commentators have identified the 'imperfect' nature of capital markets and their informational content and how this reinforces geographies of finance (Clarke and O'Connor, 1997; Tickell, 2000a). Key social and cultural processes occurring in IFC's such as face-to-face contact facilitated by social proximity result in knowledge production critical to success (Boden, 2000; Thrift, 1994.) In this logic IFC's provide a place to access information whilst the need for it to be real time and contextualised make it impossible for technology to de-centralise activities with instead companies agglomerating in the city (Clark, 2002; Sassen, 2000). Having the actors present in the city who produce this knowledge is seen as a key attribute of a successful IFC.

Third, a functionality in these geographies has been identified in the form of what Porteous $(1999,106)$ calls "inter-regional attachments" whereby the pre-eminent IFC acts as an 'access point' for financial services for other cities. As Budd (1999) noted, the amount of trade occurring in London cannot be supported solely by the national economy, but is provided from throughout Europe. Not only is London a centre for the nation but also for the region of Europe. Budd (1998) and Parr and Budd (2000) have developed this idea using Central Place Theory and the work of Losch (1941) and Christaller (1933) to explain the geographies of finance we witness. They suggest that London can be seen as a 'specialist' centre for global financial transaction because "[h]igher order activities are located at central places, with intra-industry dispersion corresponding to lower order activities" (Budd 1998, 81) which occur in other centres. Higher order centres in this model therefore have stronger attributes as an IFC. 
Although this work highlights important attributes of successful IFC's it does not fully explain the processes which sustain the advantage of any one centre and say for example why Frankfurt's markets have not grown and become the centre of European activity. If we follow the arguments to their logical conclusions Frankfurt should have become dominant for three reasons. First, the de-territorialisation of financial regulation would strip London of one of its competitive attributes whilst the UK's absence from EMU could be seen as a regulatory factors favouring Frankfurt's growth. Second, increased knowledge production should now occur in Frankfurt because of the ECB's location in the city. Third, as a result of the former factors, Frankfurt should have gained increased European centrality in financial activities. Cumulatively this should have placed the city in an upward spiral, attracting more and more financial institutions and firms and ultimately threatening London's dominance in the European hierarchy. This has not happened. Therefore, in order to understand London's continued dominance along with the slight growth of Frankfurt it seems that we need to reconsider the way we look at IFC's. Instead of viewing them in a hierarchy determined by the attribute properties of each centre the rest of this paper argues that they should be seen as the result of important interdependent networked geographies at the global and regional scale. This process is more important than any 'territorial' attribute advantages alone as highlighted in hierarchy based comparative research.

\section{Networks, articulations and flows: Explaining the IFC network}

Drawing on the ideas of a range of commentators who view the effects of contemporary globalisation as producing new network geographies it is possible to reconceptualise the way we think about IFC's. In this conceptualisation IFC networks exist as the result of an inter-meshing of global and local processes facilitated by various networks (Amin and Thrift, 1992; Allen and Pryke, 1994) producing what Sassen calls 
'global networks and linked cities' (Sassen, 2002). As Thrift long ago argued, "there is no global financial structure 'out there', as a deus ex machina, but rather a spatially distributed network of money/social power which encompasses the globe... [The] local and the global intermesh, running into one another in all manner of ways." (Thrift, 1990, 81, cited in Tickell, 2000b). Friedmann's (1995) revised model of the world city system also argues that it is 'spatial articulations' and network connections at scales from 'global financial articulations' (London) to 'multinational articulations' (Frankfurt) and national articulations (Amsterdam, Milan and Paris) which produce the world city system that exists. In Friedmann's view it is the connections between cities which are of most important not their attribute properties. A similar logic goes to make up Castells (2000) 'network society' in which the spaces of flows between 'key nodes' of the global system are central to financial activities and make certain locations pre-eminent.

The development of all these logics by Jonathan Beaverstock, Peter Taylor and colleagues (Beaverstock et al, 2000; Taylor, 2003) in relation to world cities and how it is their network which gives them 'power' in the world system further bolsters the argument for such a method of analysis. In their schema the 'strength' of a world city is defined by the networks it has and the flows produced. This is measured using the office network of transnational producer service firms and the resultant flows of capital, knowledge and people into and out of the city. In studying cities in such a way it is argued that we can better understand the interdependent network dynamics of contemporary (financial) globalisation. Based on this logic the 'Loughborough school' have produced a report investigating London and Frankfurt's relations as world cities which highlights increasing connectivity in recent years (Beaverstock et al, 2001). They argue that London and Frankfurt have developed increased network relations since the launch of the Euro as flows of knowledge, culture, power and governance develop as co-operation between firms and authorities in the two cities increases. What they do not explain however is why London has remained by far the pre-eminent European IFC as a result of this. 
Taking this framework and applying it to this question provides an opportunity to reconsider the way we understand IFC's and explain why hierarchical based approaches lead many to believe London's pre-eminence was under threat.

In a slightly different context, recent work on relational economic geographies has further shed light on the need to examine relationships in the global economy and how they give actors power and influence. According to Dicken et al $(2001,94$,original emphasis) these "networks relationships should be understood as being both structural and relational" as they "constitute structural power relations" for those networked together and "are constituted by the interactions of variously powerful actors". Only if we examine the various scales at which these networks operate can we understand any globally orientated activities. The flows within these networks are critical and as Bathelt and Glucker (2003) note, when looked at through a geographical lens help explain geographies of economic activity. Such a mode of analysis helps reveal how all places are enmeshed within a wider context and need to be understood through their relations with other actors, or in this case places. By considering any place or IFC as a result of the networks, flows and relations it has we can better understand and explain its role in a global system.

The following section therefore draws on both the network and relational geography literatures and argues that to understand London's continued pre-eminence in Europe we need to look at the role of IFC networks rather than using hierarchical comparisons of territorial attributes. It is argued that it is London's global and regional networks which have sustained its dominance whilst this is complemented by Frankfurt's role as home of the ECB. In the first section four key financial variables are quantified and in addition five non-financial variables which, amongst other attributes, help measure network connectivity. Where possible and useful, change in these values between 1998 and 2001 (the most recent data available at the time of writing) is 
provided to assess any obvious changes since the launch of the Euro ii. These values are then transformed to a base of 100 (where the pre-eminent centre's value is 100) in order to facilitate comparison between centres. This both replicates in part Reed's original work but also advances it based on more recent insights into the importance of networks in contemporary globalisation and economic geographies. Based on this analysis, semi-structured interviews were completed in London and Frankfurt. A sample of large financial organisations with a global office network was used with 12 interviews completed in all out of thirty organisations approached. Interviews were conducted in person in January 2001 and lasted between 60 and 90 minutes. Interviewees held senior positions as investment bankers or investors in insurance institutions. For reasons of confidentiality the actual names of the organisations and interviewees are not given. The aim of these interviews was to unpack these network processes which have sustained London's dominance but are not shown up through quantitative analysis.

\section{Re-conceptualising the European hierarchy as a network}

Tables 2 and 3 show the quantitative analysis of each IFC whilst tables 4 and 5 show the values transformed to a base of 100. As can be clearly seen, London remains far the pre-eminent centre based on this analysis. The value of its financial attributes are between 2.5 and 6 times greater than Frankfurt's whilst Frankfurt is far ahead of Paris, which is above Amsterdam and Milan that have minimal trade and financial significance (tables 4 and 5). Factor analysis revealed that no one variable could be held responsible for the overall importance of an IFC. The decrease in trade noted in all centres between 1998 and 2001 (table 2) is attributed to the start of the current global downturn and not the launch of the Euro. This structure strongly reflects that identified by Reed in his original work with London remaining a truly globally orientated IFC with high levels of capital availability and trade unrivalled by any other European centre (table 4 and 5). However, the data also identifies the stronger growth (or least decline) of 
Frankfurt in recent years (table 2) but despite the launch of the Euro and the location of the ECB in Frankfurt this has been insufficient to challenge London's dominance. Data acting as proxies for network connectivity (all values in table 3 except tax burden) also show significantly higher values for London than Frankfurt.

The second part of this section then draws on interviews conducted to address the specific issues raised by the launch of the Euro and to consider how network process at work may explain London's continued dominance. It highlights the networks that make London pre-eminent and also how Frankfurt, Amsterdam, Milan and Paris act as interdependent and complementary centres that help reproduce London's role.

\{ Insert tables 2,3,4 and 5 here \}

\section{Explaining London's continued dominance in the network}

It became clear during interviews that London's continued dominance in the European IFC network could be explained by its unique global-local networks. As an IFC it is both part of the European network and also wider global networks. Two important elements were highlighted by interviewees.

First, it became clear that a disproportionate amount of financial knowledge production occurs in the city. For London, both the size of its financial markets and the agglomeration of financial firms (see table 3) ensures the existence of this process as workers flow into the city from both within the UK and globally (Beaverstock and Smith, 1996). The launch of the Euro has done little to impact upon this. It was argued that the location of the ECB in Frankfurt has given the city some advantages over its previous position, attracting a new workforce to the city from within Germany and Europe, but this is a small issue compared with London's vast knowledge base driven by globally 
sourced labour. This flow of workers into the city has continued because of the global importance of the city compared to Frankfurt's relatively minor European significance.

As two interviewees summed up:

"Frankfurt is not going to get global HQ's and their workforce...ECB watchers with their intellectual infrastructure gives a good image to the city... [However] look at New York and the federal reserve in Washington, its not that significant, maybe 1600 people" (4)

"There's a point where an IFC begins to develop critical mass then you get things positively spinning off each other. So we've got an accounting infrastructure, all the skills which are associated with banking and need to be present for banking to be successfully conducted...If other large players decided the critical mass was in Frankfurt then London would have a problem - but there's no sign of it yet. Everyone wants to come to London" (9)

Two important ideas are highlighted by the above quotes. First, London remains magnet for skilled workers. The city attracts the elites needed to 'service' the financial industries from all over the world. Second, and related to the first, London also attracts key transnational businesses that Frankfurt does not making Frankfurt more of an 'international banking centre' rather than a complete IFC with strength in all markets (see table 3). This gives London a greater relational connectivity with other cities both through flows of people via migration and business travel and flows of knowledge through virtual communications. It is these networks which make London pre-eminent as the European centre of international financial knowledge whereas Frankfurt is a centre of Euro knowledge, something which attracts far fewer inward and outward flows to the city. Therefore, only if we understand why London remains a more important centre for knowledge production (because of its local-global networks) can we begin to explain the reasons for Frankfurt's limited growth.

Second, interviewees acknowledge that the UK's absence from EMU could be seen as an advantageous regulatory factor for Frankfurt. The city's centrality to the 
system should favour trading in the Euro, something that should attract business.

However, it was suggested that London's ability to exploit EMU to its best advantage through its regional networks has reduced any benefit this gave Frankfurt for two reasons. First, London is part of and has access to the political networks of the EU and can thus ensure that Euro trading regulations are moulded so to not disadvantage the city. Second, absence from EMU can be compensated for by providing trading systems which operate in the currency and are connected to Frankfurt and the ECB through communication networks allowing virtual trading. As two interviewees specifically stated:

\footnotetext{
"London is a Euro centre as it has been a dollar centre since the 60's ... Euro, Yen and Dollar transactions all congregate in London. Being part of the European Community will facilitate doing cross-border trades and is helpful to London because most regulation is laid down at the European level " (6)

"The hard fact is that London is a Euro centre just as it has been a Dollar centre for over fifty years. The processing systems work in Dollars - the same thing is now precisely the same for the Euro. You can pay premiums at Lloyds in Euro's, you can use money transfer systems to push money down the wire to or from Frankfurt. London is a Euro centre - a European asset not just a British asset" (12)
}

These comments clearly highlight the connectivity and relational nature of activities in London. Not only is the city connected to Europe by membership of the EU and the political networks this makes London part of, but also ICT based trading systems link London to both Europe and other global IFC's. Connections to the New York and Tokyo markets are particularly important. This is a unique position, reflecting Friedmann's idea that London is a global financial articulation. London provides services and financial fluidity unrivalled by any other IFC based on its regional European networks which allow trading in the Euro and also its global networks which allow firms in London to trade in other global markets and currencies. As a result one interviewee argued that "[t]he major players have consolidated business leading up to the launch of the Euro" (2) and wanted to be in London whilst another commented that "an IFC must 
be a hypermarket, not a specialist retailer, with built up expertise, a financial centre in its entirety" (8). London's global and regional networks allow this. Frankfurt lacks this global 'deep' integration which makes London so influential. Instead, it has adopted a new role as the location of the ECB which gives them a heightened significance and new regional networks to other European IFC's like Amsterdam, Milan and Paris.

The complementary network of European IFC's

A new way of conceptualising the geographies of European finance as a network is therefore needed. EMU has reorganised these networks in some ways but not changed their key properties. London's importance has been maintained because of the relationships and connections it has, particularly at the global scale. This help reproduces its role. Frankfurt's growth has been based around Euro centred transactions giving it a new significance beyond its role within Germany through new network articulations. The reorganised European network means Frankfurt has strengthened relations with London whilst relations with Amsterdam, Milan and Paris are also responsible for recent growth as increasing flows of trade develop because of the ECB's location in the city. However, London remains pre-eminent providing truly global service and connectivity which all European IFC's need to access and rely upon. Therefore there is an interdependency of centres which is reproduced by the networks of trade and knowledge between each city which exist in varying strengths. London serves a global role, Frankfurt a regional Euro based role, whilst Amsterdam, Milan and Paris act as domestic centres. Most interviewees (10 out of 12) suggested such a phenomena was important and three specifically stated:

\footnotetext{
"There could be a kind of specialisation of different financial centres meaning for example that Paris and Frankfurt are importing a lot of service from London - meaning they need the international structure London has. Maybe the idea of competition has been seen as too strong. There is enormous financial growth in Europe and all centres can benefit. London benefits as
} 
Paris and Frankfurt develop their markets and there are certain services they cannot offer - especially in foreign exchange, in the eurobond area - that you have to look to London. There is a complementarity of centres. . Frankfurt can't be a New York, but is it so bad to be a Washington or Chicago?" (1)

"The imperial thesis of London versus Frankfurt is not useful, Frankfurt can import useful services from London, and in return be a key European link for the city. The network model is already being alluded to whereby several cities each have their own role in European finance but remain interconnected" (3)

"You need to differentiate between the domestic financial market and the wider [international] financial markets. All the evidence suggests in the international financial markets - bonds, foreign exchange - London continues to account for the largest share of activities. Where you might get consolidation of activities as a result of the Euro is in domestic financial transactions and that won't necessarily mean a loss of business to London. London is an international centre and offers largely different services dealing with clients all over the world. It almost offshore to the UK in the way it operates. Paris and Frankfurt want a bigger slice of the European action and you have to take that into account. Having said that, there is a complementarity as regards their services. In effect each has a role in its own right" (9)

Those working in the IFC's of London and Frankfurt are thus acutely aware of such a relationship developing and its implications for the functioning of European finance. It is interesting to note that interviewees in Frankfurt focussed more upon how Frankfurt can complement London in its role as a Europe's preeminent financial centre whilst those in London focussed upon how the City has a dominant role and this has continued. Undoubtedly the increased connectivity and relationships between London and Frankfurt in recent times have reinforced this belief and negated any competitive behaviour. The two IFC's complement one another and work in a synergistic way to service the financial needs of Europe's businesses. This can be seen in the strategy of many of the key transnational financial firms who continue to have offices in both city's but with most having their $\mathrm{HQ}$ or largest office in London. A new form of relationship has developed in many cases between these offices with flows of work and personnel between London and Frankfurt intensifying and the 'London-Frankfurt commute' from City Airport to 
Frankfurt now being something common to those involved in finance. At the same time firms in Amsterdam, Milan and Paris have developed increasing relations with Frankfurt. For these firms the networks and relations between cities are now critical. As a result there is a European network of IFC's rather than a hierarchy. Each centre has a specific role that is reproduced by its interdependent relationships with other IFC's. However, London remains dominant in this network because of its unique global-local networks that other European IFC's are dependent upon.

\section{Conclusions: The IFC network}

In this paper it has been argued that the geography of European IFC's should be depicted as a relational network in contemporary globalisation. The continued preeminence of London in the European financial network can be explained when such an approach is used. It has cultivated a global network that means it is a centre for global financial transactions and therefore attracts many of the key global financial institutions and firms. Flows of capital, knowledge, trade, people and political influence (within both the EU and wider global financial networks) result from and reinforce this role in the network. No other IFC in Europe has achieved this to such an extent and thus London's dominance of European networked financial systems. The launch of EMU has simply re-organised the European network to give Frankfurt a new regional role. The city has been growing in recent years but principally based on domestic trade and increased Euro based trading thanks to the location of the ECB in the city. It cannot however provide the same services as London because of its lack of global connectivity. Adding an attribute to the centre in the form of the ECB has not altered this although the reorganisation of the European network it caused has benefited Frankfurt. For Frankfurt, 
and other European IFC's then, London still has a vital role for truly global trading and for European financial activities of global firms.

At the same time however all of the European IFC's are complementary to oneanother with Frankfurt's European role complementing London's more global role. This has produced increased connectivity and flows between the two centres since the launch of the Euro. These flows of capital, trade in each-others markets and people have become increasingly important. Amsterdam, Milan and Paris act as 'national' centres that complement both London and Frankfurt. In effect then London is now relationally closer to Frankfurt because of the launch of the Euro whilst Amsterdam, Milan and Paris remain relationally more distant. The proximity between London and Frankfurt has not however lead to an eroding of London's pre-eminence but has instead reinforced it. Global-local networked interdependencies therefore exist between European IFC's and produce an European network of IFC's. Analysing the system from this perspective helps explain why London has remained dominant since the launch of EMU. 


\section{Acknowledgements}

I am indebted to Jon Beaverstock's invaluable help and advice regarding the planning and execution of this research and his comments on previous drafts of this paper. This project was undertaken in parallel to Jon Beaverstock, Michael Hoyler, Kathy Pain and Peter Taylor's Anglo-German Foundation Study ‘Comparing London and Frankfurt as World Cities,' and I thank Jon Beaverstock again for allowing me access to secondary sources collected as part of this study. 


\title{
References
}

\author{
Allen J and Pryke M 1994 The production of service space. Environment and Planning \\ D: society and space $12453-475$
}

Amin A and Thrift NJ 1992 Neo-Marshallian nodes in global networks. International journal of Urban and regional research 16(4) 571 - 587.

Banker The 1999 Survey of international banking, November 1999.

Bathelt $\mathbf{H}$ and Gluckler J 2003 Toward a relational economic geography. Journal of Economic Geography $3117-144$.

Beaverstock JV and Smith J 1996 Lending jobs to global cities: Skilled international labour migration, investment banking and the City of London. Urban Studies $331377-$ 1394.

Beaverstock JV Smith RG and Taylor PJ 2000 World city network: A new metageography? Annals, Association of American Geographers 901 123-134

Beaverstock JV, Hoyler M, Pain K and Taylor PJ 2001 Comparing London and Frankfurt as world cities. A relational study of contemporary urban change. AngloGerman foundation for study of industrial society, London.

Bindemann K 1999 The future of European financial centres. Routledge London. 
BIS 2001 Bank for international settlements Central bank survey of foreign exchange and derivatives markets. http://www.bis.org/publ. Accessed $11^{\text {th }}$ October 2002.

BIS 2002 Bank for international settlements International statistics quarterly review, September 2002. http://www.bis.org/statistics/index.htm Accessed $11^{\text {th }}$ October 2002.

Boden D 2000 Words in action; information, instantaneity and global futures trading in Adam B, Beck U and Von Loon (eds) The risk society and beyond. Sage, London.

Budd L 1995 Globalisation, territory and strategic alliances in different financial centres Urban studies $32345-360$.

Budd L 1998 Global cities and finance: a troubled relationship. In Gravesteijn S G E, van Griensven S and de Smidt M C (eds) Timing Global Cities Gedrukt door drukkeril Elinkwijk b.v. Utrect 67-83.

Budd L 1999 Globalisation and International Financial Centres. In Martin R ed Money and the space economy. Wiley Chichester 115-137.

Castells M 2000 The rise of the network society. Blackwell, Oxford.

Christaller W 1933 Die zentralen Orte in Süddeutschland. Gustav Fischer Jena.

Clark GL 2000 Pension fund capitalism. Oxford University Press Oxford.

Clark GL 2002 London in the European financial services industry: locational advantage and product complementarities. Journal of Economic Geography 2 433-453. 
Clark GL and O'Connor K 1997 The informational content of financial products and the spatial structure of the global finance industry. In Cox KR (ed) Spaces of globalization. Reasserting the power of the local. The Guilford press London.

Dicken P, Kelly PF, Olds K and Yeung HW 2001 Chains and network, territories and scales: towards a relational framework for analysing the global economy. Global networks 1(2) 89-112.

Fairlamb D 1999 Dueling markets. Institutional investor 5.

Fortune 2002 The 2002 Fortune 500 Fortune New York.

Friedmann J 1995 Where we stand: a decade of world city research. In Knox PL and Taylor PJ (eds) World Cities in a World System. Cambridge University Press, Cambridge 21-47.

Healey and Baker 2001 Healey and Baker Euro Cities monitor 2001 Cushman and Wakefield London.

HM Treasury 2003 UK membership of the single currency: an assessment of the five economic tests. HM Treasury London.

Holfreich CL 1999 Finanzplatz Frankfurt. Von der mittelalterlichen messestadt zum europäischen bankenzentrum. Beck Munich.

Johnson C 1996 In with the Euro out with the Pound. Penguin London. 
Keil R and Ronneberger K 2000 The globalization of Frankfurt am Main: core periphery and social conflict. In Marcuse $\mathbf{P}$ and van Kempen R (eds) Globalizing cities: a new spatial order? Blackwell Oxford 220-248.

Losch A 1941 Die räumliche Ordnung der Wirtschaft Gustav Fischer Jena.

Leyshon A and Thrift N 1992 Liberalisation and consolidation: the single European market and the remaking of European financial capital. Environment and Planning A 26 (12) $1861-1890$.

Martin R 1999 The new economic geography of money in Martin R ed Money and the space economy Wiley Chichester

Michie RC 1991 The city of London: continuity and change 1850 - 1990. Macmillan London.

O'Brien R 1992 Global financial integration: The end of Geography. Royal Institute of International Affairs, London.

OECD 2002 Taxation statistics

http://www.oecd.org/topicstatsportal/0,2647,en $28254956351111111,00 . \mathrm{html}$ Accessed $11^{\text {th }}$ October 2002.

Parr JB and Budd L 2000 Financial services and the urban system: an exploration. Urban studies 37(3) 593-610. 
Porteous D 1999. The development of financial centres: location, information externalities and path dependence In Martin R (ed) Money and the space economy Wiley Chichester 95-114.

Pryke M 1991 An international city going global: spatial change in the City of London. Environment and Panning D: society and Space 9 197-222.

Pryke M 1994 Looking back on the space of a boom: (re)developing the spatial matrices in the City of London. Environment and Planning A $26235-264$

Reed H C 1981 The pre-eminence of international financial centres. Praeger, New York.

Sassen S 2000. Cities in a world economy. Pine Forge Press London.

Sassen S (ed) 2002 Global networks linked cities. Routledge London.

Schamp E 1999 The system of German financial centres at the cross roads: from national to European scale. In Wever E (ed) Cities in perspective I: economy, planning and the environment. Van Gorcum Assen 83-98.

Taylor PJ, Beaverstock JV, Cook G and Pandit N 2003 Financial service clustering and its significance for London Corporation of London, London.

Thrift NJ 1987 The fixers: the urban geography of international commercial capital in Henderson J and Castells M eds Global restructuring and territorial development Sage, London 203-233 
Thrift NJ 1990 Doing regional geography in a global system: the new international financial system, the city of London and the South East of England 1984-87. In Johnston RJ, Hauer J and Hoekveld GA eds Regional geography: current developments and future prospects. Routledge, London 180-207

Thrift NJ 1994 On the social and cultural determinants of International Financial Centres: the case of the City of London. In Corbridge S, Martin R and Thrift $\mathbf{N}$ eds Money, power and Space. Blackwell Oxford 327-355.

Thrift NJ and Leyshon A 1992 In the wake of money. The city of London and the accumulation of value in Budd $\mathbf{L}$ and Whimster $\mathbf{S}$ eds Global finance and urban living. A study of metropolitan change Routledge London 282-311.

Tickell A 2000a Dangerous derivatives: controlling and Creating risks in international money. Geoforum $3187-99$

Tickell A 2000b Finance and localities. In Clark GL, Feldman MP and Gertler MS eds The oxford handbook of economic geography. Oxford university press Oxford 230-252.

World federation of exchanges 2002 Annual equity indexes. http://www. fibv.com/WFE/home.asp?action=document\&menu=27. Accessed $11^{\text {th }}$ October 2002. 
Table 1. Howard Reed's top ten IFC's, 1980.

\begin{tabular}{|c|c|c|c|}
\hline Rank & City & $\begin{array}{l}\text { Overall } \\
\text { Score }\end{array}$ & Division \\
\hline 1 & London & 100 & Supranational \\
\hline 2 & New York & 85 & $\begin{array}{l}1^{\text {st }} \text { order } \\
\text { supranational }\end{array}$ \\
\hline 3 & Paris & 83 & $\begin{array}{l}2^{\text {nd }} \text { order } \\
\text { supranational }\end{array}$ \\
\hline 4 & Tokyo & 78 & $\begin{array}{l}1^{\text {st }} \text { order } \\
\text { supranational }\end{array}$ \\
\hline 5 & Frankfurt & 78 & $\begin{array}{l}2^{\text {nd }} \text { order } \\
\text { supranational }\end{array}$ \\
\hline 6 & Zurich & 76 & $\begin{array}{l}2^{\text {nd }} \text { order } \\
\text { supranational }\end{array}$ \\
\hline 7 & Amsterdam & 75 & $\begin{array}{l}2^{\text {nd }} \text { order } \\
\text { supranational }\end{array}$ \\
\hline 8 & San Francisco & 74 & $\begin{array}{l}2^{\text {nd }} \text { order } \\
\text { supranational }\end{array}$ \\
\hline 9 & Chicago & 72 & $\begin{array}{l}2^{\text {nd }} \text { order } \\
\text { supranational }\end{array}$ \\
\hline 10 & Hamburg & 71 & $\begin{array}{l}2^{\text {nd }} \text { order } \\
\text { supranational }\end{array}$ \\
\hline
\end{tabular}

Source: Reed (1981) 
Table 2. Europe's new hierarchy of IFC's (incorporating financial measures only).

\begin{tabular}{|c|c|c|c|c|c|}
\hline Factor & Amsterdam & Frankfurt & London & Milan & Paris \\
\hline Daily Forex (US\$ bn) * & 30.00 & 88.00 & 504.00 & 17.00 & 48.00 \\
\hline $98-01$ change $(\%) *$ & -26.83 & -6.68 & -20.92 & -39.72 & -33.24 \\
\hline Daily Derivatives (US\$ bn) ** & 5.30 & 34.40 & 170.80 & 4.40 & 45.80 \\
\hline $98-01$ change $(\%)$ ** & 1.00 & 149.00 & 131.00 & 83.00 & 105.00 \\
\hline Loans value (US\$ bn) ** & 248.00 & 765.00 & 1671.00 & 121.00 & 464.00 \\
\hline 98 - 01 change $(\%)$ ** & 3.15 & 27.20 & 98.11 & -69.84 & 17.65 \\
\hline $\begin{array}{l}\text { Equities traded } \\
\text { internationally (US\$m)*** }\end{array}$ & 0.400 & 1591.00 & 5909.00 & 0.780 & 0.82 \\
\hline
\end{tabular}

Sources:

${ }^{*} \mathrm{BIS}(2001)$

** BIS (2002)

*** World federation of exchanges (2002) 
Table 3. Revised hierarchy of non-factors in IFC success.

\begin{tabular}{|c|c|c|c|c|c|}
\hline Factor & Amsterdam & Frankfurt & London & Milan & Paris \\
\hline Telecommunications quality score * & 0.40 & 0.67 & 1.22 & 0.15 & 0.93 \\
\hline No. HQ's from top 500 ** & 1.00 & 3.00 & 33.00 & 0.00 & 9.00 \\
\hline Tax burden *** & 40.00 & 36.00 & 37.00 & 42.00 & 45.00 \\
\hline Labour score ${ }^{* \star \star *}$ & 0.36 & 0.60 & 1.21 & 0.31 & 0.85 \\
\hline No. Foreign banks • & 30.00 & 82.00 & 420.00 & 25.00 & 81.00 \\
\hline No. Service offices •. & 39.00 & 57.00 & 97.00 & 56.00 & 71.00 \\
\hline
\end{tabular}

Sources:

* Healey and Baker 2001

** Fortune 2002

*** OECD 2002

**** Healey and Baker 2001

- Banker 1999

- GaWC data set $6^{\text {iii }}$ 
Table 4. Hierarchy of financial factors transformed to a base of 100 (where the pre-eminent value scores 100 and all others are scaled against this as with Reed's original work.)

\begin{tabular}{llllll}
\hline Factor & Amsterdam & Frankfurt & London & Milan & Paris \\
\hline Daily Forex (US\$ bn) & 6.0 & 17.5 & 100.0 & 3.4 & 9.5 \\
$98-01$ rise (\%) & 34.1 & 100.0 & 71.5 & 19.3 & 54.5 \\
Daily Derivatives (US\$ bn) & 3.1 & 20.1 & 100.0 & 2.6 & 26.8 \\
$98-1$ change (\%) & 0.7 & 100.0 & 87.9 & 55.7 & 70.5 \\
Loans value (US\$ bn) & 14.8 & 45.8 & 100.0 & 7.2 & 27.8 \\
$98-01$ change (\%) & 3.2 & 27.7 & 100.0 & 0.0 & 18.0 \\
Equities traded internationally (US\$m) & 0.0 & 5.7 & 100.0 & 0.0 & 0.0 \\
\hline
\end{tabular}


Table 5. Non-financial factors converted to base of 100 (where 100 is the pre-eminent centre, London)

\begin{tabular}{llllll}
\hline Factor & Amsterdam & Frankfurt & London & Milan & Paris \\
\hline Telecommunications quality score & 32.8 & 54.9 & 100.0 & 12.3 & 76.2 \\
No. HQ's from top 500 & 3.0 & 9.1 & 100.0 & 0.0 & 27.3 \\
Tax burden & 88.9 & 100.0 & 97.2 & 83.3 & 75.0 \\
Labour score & 29.8 & 49.6 & 100.0 & 25.6 & 70.2 \\
No. Foreign banks & 7.1 & 19.5 & 100.0 & 6.0 & 19.3 \\
No. Service offices & 40.2 & 58.8 & 100.0 & 57.7 & 73.2 \\
Total value & 5.5 & 21.3 & 100.0 & 3.5 & 12.7 \\
\end{tabular}


i Reed measured this using the following variables: Local bank HQ's; Local banks direct links; Foreign bank office; Foreign bank direct links; Foreign financial assets; Foreign financial liabilities; Local bank branch / representative direct links; and Foreign bank / representative office.

ii Data on number of service offices and foreign banks is from 1998 only as it proved impossible to find a more recent and equally comprehensive data set to facilitate accurate comparison.

iii The data used is from Data Set 6 from the GaWC Research Group and Network (http://www.Iboro.ac.uk/gawc/). It was created by P.J. Taylor and D.R.F. Walker as part of their project "World City Network: Data Matrix Construction and Analysis" and is based on primary data collected by J.V. Beaverstock, R.G. Smith and P.J. Taylor (ESRC project "The Geographical Scope of London as a World City" (R000222050)). 